\title{
TOKSISITAS AKUT EKSTRAK ETANOL DAUN KIRINYUH (CHROMOLAENA ODORATA (L) R.M. KING \& H. ROB) PADA MENCIT PUTIH JANTAN
}

\author{
Nirwanto $^{1)}$, Aried Eriadii), Helmi Arifin ${ }^{2)}$ \\ ${ }^{1)}$ Sekolah Tinggi Ilmu Farmasi (STIFARM) Padang \\ ${ }^{2)}$ Fakultas Farmasi Universitas Andalas Padang \\ e-mail:
}

\begin{abstract}
The acute toxicity of ethanol extracts from Kirinyuh (Chromolaena odorata (L) R.M. King $\& H$. Rob) leaves to white mice males has been done. Parameters toxicity observed were LD50 and delayed toxic effects for 14 days of observation including changes in weight, volume of water consumption, and relative weight of the organs like heart, liver, kidneys, stomach and lungs. The ethanol extract of Chromolaena odorata (L) R.M King \& $\mathrm{H}$. Rob leaves orally at a dose of $4 \mathrm{~g} / \mathrm{kgBB}$, $8 \mathrm{~g} / \mathrm{kgBB}$ and $16 \mathrm{~g} / \mathrm{kgBB}$, showed that was categorized practically non-toxic (LD50>15 g/ $\mathrm{kgBB}$ ). Delayed toxic effects are seen from the significant differences in body weight, the volume of water, relative organ weight of lung and stomach $(P<0.05)$. There were no significant differences in the relative organ weight of the heart, liver and kidneys $(P<0.05)$.
\end{abstract}

Keywords: LD50, delayed toxicity, chromolaena odorata (L) R.M. King \& H. Rob

Telah dilakukan pengujian toksisitas akut ekstrak etanol daun Kirinyuh Chromolaena odorata (L) R.M. King \& H. Rob. Parameter toksisitas yang diamati adalah LD50 dan efek toksik tertunda selama 14 hari pengamatan yang meliputi perubahan berat badan, volume konsumsi air minum, dan berat relatif organ dari jantung, hati, ginjal, lambung, dan paru-paru. Pemberian ekstrak etanol daun kirinyuh (Chromolaena odorata (L) R.M. King \& H. Rob) secara oral dengan dosis $4 \mathrm{~g} / \mathrm{kgBB}$, $8 \mathrm{~g} / \mathrm{kgBB}$ dan $16 \mathrm{~g} / \mathrm{kgBB}$, menunjukkan bahwa ekstrak ini termasuk kategori praktis tidak toksik (LD50 $>15 \mathrm{~g} / \mathrm{kgBB}$ ). Efek toksik tertunda terlihat dari adanya perbedaan signifikan pada berat badan, volume air minum, berat relatif organ paru dan lambung $(\mathrm{P}<0,05)$. Tidak terdapat perbedaan yang signifikan pada berat relatif organ jantung, hati, dan ginjal $(\mathrm{P}<0,05)$.

Kata kunci: LD50, toksisitas tertunda, chromolaena odorata (L) R.M. King \& H.Rob.

\section{PENDAHULUAN}

Dewasa ini penelitian dan pengembangan tumbuhan obat baik di dalam maupun di luar negeri berkembang dengan pesat. Penelitian yang berkembang terutama pada segi farmakologi maupun fitokimia berdasarkan indikasi tumbuhan obat yang telah digunakan sebagian masyarakat dengan khasiat yang teruji secara empiris. Hasil penelitian tersebut, tentunya lebih memantapkan para pengguna tumbuhan obat akan khasiat maupun kegunaannya (Dalimartha, 2000). Obat tradisional adalah bahan atau ramuan ba- han yang berupa tumbuhan, bahan hewan, bahan mineral, sediaan cairan (galenik), atau campuran dari bahan tersebut yang secara turun temurun telah digunakan untuk pengobatan dan dapat diterapkan sesuai dengan norma yang berlaku di masyarakat (Badan Pengawas Obat dan Makanan Republik Indonesia, 2014).

Meskipun obat tradisional sudah dimanfaatkan sejak lama namun tidak sepenuhnya aman, karena obat tradisional merupakan senyawa asing bagi tubuh, sehingga sangatlah penting mengetahui potensi ketoksikannya. Efek toksik pada 
makhluk hidup dapat terlihat dan dapat juga tidak bila dosis yang diserap relatif kecil kerusakannya dapat terbatas pada sel saja (Koeman, 1987).

Kirinyuh (Chromolaena odorata (L) R.M. King \& H. Rob) merupakan salah satu jenis tumbuhan dari family Asteraceae/Compositae. Daunnya mengandung beberapa senyawa utama seperti tannin, fenol, flavonoid, saponin, dan steroid. Minyak esensial dari daun kirinyuh memiliki kandungan a pinene, cadinene, camphora, limonene, b-caryophyllene, dan candinol isomer (Inya-agha et al., 1987).

Secara tradisional daun kirinyuh digunakan sebagai obat dalam penyembuhan luka, obat kumur untuk pengobatan sakit pada tenggorokan, obat batuk, obat malaria, antimikroba, sakit kepala, antidiare, astringent, antispasmodik, antihipertensi, antiinflamasi, dan diuretik (Vital \& Rivera, 2009). Dalam usaha meningkatkan pemanfaatan tumbuhan daun kirinyuh (Chromolaena odorata (L) R.M.King \& H.Rob) sebagai obat, baik penggunaan tradisional, penggunaan simplisia, maupun fitofar diperlukan informasi lengkap mengenai keamanan pemakaian obat tradisional. Menurut Lu (1995) untuk menilai keamanan tersebut perlu dilakukan uji toksisitas yang meliputi uji toksisitas akut, toksisitas sub akut, toksisitas kronis, dan uji toksisitas spesifik.

Pada penelitian sebelumnya telah dilakukan pengujian terhadap aktivitas antimikroba ekstrak daun kirinyuh, hasilnya menunjukkan positif terhadap bakteri Bacillus subtillis, Staphylococcus aureus dan Salmonella typhimurium (Vital \& Rivera, 2009), juga telah dilakukan pengujian terhadap ekstrak etanol daun kirinyuh untuk pengobatan luka pada mencit jantan, kontrol dan pembanding, hasilnya menunjukkan bahwa ekstrak etanol daun kirinyuh memberikan efek penyembuhan luka yang lebih cepat (Yenti et al., 2011).

Mengingat luasnya pemakaian daun kirinyuh sebagai obat, maka penggunaan tanaman ini sebagai obat perlu dilakukan serangkaian uji, seperti uji khasiat, toksisitas secara praklinik dan uji klinik. Berdasarkan hal tersebut telah dilakukan uji toksisitas akut ekstrak etanol daun kirinyuh yang meliputi penentuan LD50 dan efek toksik tertunda selama 14 hari untuk menetapkan potensi ketoksisitasannya terhadap mencit putih jantan, baik digunakan secara tradisional maupun sebagai obat.

\section{METODE PENELITIAN}

Alat

Digunakan timbangan hewan (Ohaus), timbangan analitik (Precisa), gunting, sentrifus (DKC 1008T), gelas ukur (Iwaki), kaca arloji, plat tetes, aluminium foil, tabung reaksi (Iwaki), waterbath (Memmert), cawan penguap, spatel, spuit, sonde, alat bedah, pinset, beacker glass, dan rotary evaporator (IKA).

\section{Bahan}

Bahan yang digunakan adalah daun segar daun kirinyuh (Chromolaena odorata (L) R.M. King \& H. Rob), Natrium carboxy methyl cellulose (Na-CMC) (PT Brataco), plat KLT Silica gel $\mathrm{GF}_{254}$ (Merck), makanan standar mencit (PELLET HI-PRO-VITE 511) (PT Pokphand), etanol 70\% (PT Brataco), asam klorida (Merck), kloroform (PT Brataco), magnesium (PT Brataco), asam sulfat (Merck), metanol (PT Brataco), quercetin (Merck), dikloroetana (Merck), dan mencit putih jantan. 


\section{Prosedur Penelitian}

\section{A. Pengambilan Sampel}

Sampel yang digunakan adalah tumbuhan daun kirinyuh (Chromolaena odorata (L) R.M. King \& H. Rob). Bagian yang diambil adalah daunnya yang segar di daerah Bypass KM.17 Padang, Sumatera Barat.

\section{B. Identifikasi Tumbuhan}

Identifikasi tumbuhan dilakukan di Herbarium Andalas (ANDA), Jurusan Biologi, Fakultas Matematika dan Ilmu Pengetahuan Alam (FMIPA), Universitas Andalas (UNAND) Padang, Sumatera Barat.

\section{Penyiapan Simplisia}

Pada umumnya, proses pembuatan simplisia melalui tahap seperti berikut. Pengumpulan bahan baku, sortasi basah, pencucian, perajangan, pengeringan, sortasi kering, penyimpanan dan pemeriksaan mutu (Departemen Kesehatan Republik Indonesia, 1985).

\section{Pembuatan Ekstrak}

Dari proses ini didapatkan serbuk simplisia daun kirinyuh sebanyak 3.984 g. Kemudian diambil $1.500 \mathrm{~g}$ dibagi menjadi 10 bagian yang masing-masingnya sebanyak 150 g. Kemudian masukan masing-masing bagian serbuk simplisia kering ke dalam 10 botol maserator yang gelap, tambahkan 10 bagian pelarut (etanol 70\%). Rendam selama 6 jam pertama sambil sekalikali diaduk, kemudian diamkan selama 18 jam pada temperatur ruangan (kamar). Pisahkan maserat dengan cara filtrasi menggunakan kain flanel, ulangi proses penyarian sebanyak dua kali dengan jenis dan jumlah pelarut yang sama (remaserasi). Kumpulkan semua maserat kemu- dian dipekatkan dengan rotary evaporator sampai didapatkan ekstrak kental (Departemen Kesehatan Republik Indonesia, 2008). Setelah itu hitunglah hasil rendemen ekstrak.

$\%$ Rendemen $=\frac{\text { Berat ekstrak kental }}{\text { Berat simplisia kering }} \times 100 \%$

\section{E. Karakterisasi Ekstrak Etanol Daun Kirinyuh}

Karakterisasi ekstrak etanol daun kirinyuh yang dilakukan di antaranya susut pengeringan, penentuan kadar abu, identitas, organoleptis, kadar senyawa larut air dan kadar senyawa larut etanol (Departemen Kesehatan Republik Indonesia, 2000).

\section{F. Uji Kandungan Kimia}

Pemeriksaan fitokimia ekstrak dilakukan di antaranya uji alkaloid, flavonoid, steroid, terpenoid dan saponin. Serta pengujian kromatogram lapis tipis dan kadar flavonoid total (Departemen Kesehatan Republik Indonesia, 1980).

\section{G. Persiapan Hewan Percobaan}

Hewan yang digunakan adalah mencit putih jantan umur 2-3 bulan dengan berat antara 2030 gram sebanyak 20 ekor, Sebelum penelitian dilakukan, mencit diaklimatisasi selama 7 hari dengan diberi makan dan minum yang cukup. Mencit yang akan digunakan adalah mencit yang sehat dan tidak menunjukkan perubahan berat badan berarti (deviasi maksimal 10\%) serta secara visual menunjukkan perlakuan yang normal.

\section{H. Dosis Uji}

Dosis ekstrak daun kirinyuh yang diberikan pada mencit putih jantan adalah $4 \mathrm{~g} / \mathrm{KgBB}, 8 \mathrm{~g} /$ $\mathrm{KgBB}$, dan $16 \mathrm{~g} / \mathrm{KgBB}$ yang diberikan secara oral. 


\section{Tahap Pengujian}

Sebelum diberi perlakuan masing-masing mencit ditimbang lalu mencit dibagi 4 kelompok. Masing-masing kelompok terdiri dari 5 ekor mencit, dengan perlakuan sebagai berikut.

a. Kelompok I (kontrol): hanya diberi suspensi $\mathrm{Na}$ CMC 0,5\%

b. Kelompok II: diberi ekstrak daun kirinyuh dengan dosis $4 \mathrm{~g} / \mathrm{KgBB}$

c. Kelompok III: diberi ekstrak daun kirinyuh dengan dosis $8 \mathrm{~g} / \mathrm{KgBB}$

d. Kelompok IV: diberi ekstrak daun kirinyuh dengan dosis $16 \mathrm{~g} / \mathrm{KgBB}$

\section{J. Penentuan Nilai LD50 dan Pengamatan Gejala Toksik yang Menyertai}

Nilai LD50 ditentukan dengan menghitung jumlah kematian hewan uji selama 24 jam yang disebabkan oleh pemberian tunggal sediaan uji pada kelompok mencit dengan dosis $4 \mathrm{~g} / \mathrm{KgBB}$, $8 \mathrm{~g} / \mathrm{KgBB}$, dan $16 \mathrm{~g} / \mathrm{KgBB}$. Hewan uji dikelompokkan secara acak menjadi 4 kelompok yang tiap kelompok terdiri dari 5 ekor (satu kelompok sebagai kontrol dan tiga kelompok perlakuan dengan berbagai dosis). Masing-masing kelompok perlakuan diberikan suspense ekstrak secara oral dengan dosis $4 \mathrm{~g} / \mathrm{KgBB}, 8 \mathrm{~g} / \mathrm{KgBB}$, dan 16 $\mathrm{g} / \mathrm{KgBB}$, sedangkan kelompok kontrol negatif hanya diberikan larutan $\mathrm{Na}$ CMC 0,5\%. Jumlah hewan uji yang mati dalam 24 jam setelah pemberian ekstrak dihitung. Sementara itu, setelah pemberian suspense ekstrak dilakukan pengamatan gejala-gejala toksik yang menyertai selama 3 jam. Untuk hewan yang mati dilakukan pembedahan dan dilakukan penentuan berat relatif dari organ paru-paru, hati, ginjal, jantung dan lambung.

\section{K. Evaluasi Efek Toksik Tertunda Selama 14 Hari}

Pada mencit yang masih hidup mulai dari 24 jam sampai dengan 14 hari setelah pemberian sediaan uji, selain diamati gajala-gejala toksik yang timbul juga dilakukan penimbangan berat badan tiap 48 jam, pengukuran konsumsi air minum, dan pada hari ke-14 hewan percobaan dikorbankan untuk penentuan berat relatif organ jantung, hati, ginjal, lambung dan paruparu.

\section{Analisis Data}

Data dari hasil penelitian ini dianalisis secara statistik dengan menggunakan analisis varian (ANOVA) satu arah dan dua arah dilanjutkan dengan uji wilayah berganda Duncan (Duncan's Multiple Range T-test) (Jones, 2010).

\section{HASIL DAN PEMBAHASAN}

Daun kirinyuh yang digunakan pada penelitian ini adalah dari spesies Chromolaena odorata (L) R.M.King \& H. Rob. famili Asteraceae/Compositae.

Proses ekstraksi sampel dilakukan dengan metode maserasi. Pemilihan metode ini karena sampel yang digunakan berupa daun segar. Daun segar kirinyuh ditimbang sebanyak $5 \mathrm{~kg}$ lalu dilakukan pencucian, kemudian dirajang dengan tujuan agar pelarut dapat berpenetrasi dengan mudah sehingga penarikan zat aktif lebih sempurna, kemudian pengeringan dengan cara diangin-anginkan selama 7 hari sampai kering dan penghalusan, sehingga diperoleh serbuk kering sebanyak 3.984 g. Sebanyak 1.500 g dimaserasi menggunakan pelarut etanol 70\%. Penggunaan penyari etanol $70 \%$ karena sampel yang diguna- 
kan adalah sampel kering sehingga dibutuhkan air untuk membasahi sampel sehingga sel-sel akan mengembang dan pelarut akan lebih mudah berpenetrasi untuk mengikat senyawa-senyawa yang terkandung di dalam sampel.

Penggunaan etanol sebagai pelarut universal disebabkan karena sifatnya yang mudah melarutkan senyawa zat aktif baik yang bersifat polar, semi polar, dan non-polar. Serta kemampuannya untuk mengendapkan protein dan menghambat kerja enzim sehingga dapat menghindari proses hidrolisa dan oksidasi.

Maserasi dilakukan selama 1 hari dengan 3 kali pengulangan. Proses maserasi ini dilakukan dengan menggunakan botol kaca berwarna gelap dan di tempat yang terlindung cahaya. Hal ini bertujuan untuk menghindari terjadinya penguraian struktur zat aktif terutama untuk senyawa yang kurang stabil terhadap cahaya. Satu bagian serbuk kering simplisia dimaserasi dalam botol gelap tertutup dengan 10 bagian pelarut, rendam selama 6 jam pertama sambil sekali-sekali diaduk, kemudian diamkan selama 18 jam. Pisahkan maserat dengan cara penyaringan, ulangi proses penyarian sekurang-kurangnya dua kali dengan jenis dan jumlah pelarut yang sama.

Semua maserat yang diperoleh diuapkan dengan rotary evaporator lalu dipekatkan dengan waterbath sampai didapat ekstrak kental. Diperoleh ekstrak kental sebanyak 91,0670 g dengan nilai rendemen 6,07\%. Setelah didapatkan ekstrak kental, selanjutnya, daun kirinyuh (Chromolaena odorata (L) R.M. King \& H. Rob) dievaluasi melalui parameter spesifik dan parameter nonspesifik (Departemen Kesehatan Republik Indonesia, 2000) agar kualitas ekstrak dapat dikontrol untuk selanjutnya diproduksi sebagai calon fitofarmaka.

Dari penentuan organoleptis, didapatkan ekstrak dengan warna hijau pekat, rasanya pahit, bau khas aromatis, dan bentuknya kental. Penentuan organoleptis ini termasuk salah satu parameter spesifik yang ditentukan dengan pancaindra dan bertujuan untuk pengenalan awal secara sederhana dan subjektif. Selanjutnya dilakukan pemeriksaan karakterisasi terhadap ekstrak daun kirinyuh yang meliputi pemeriksaan uji non spesifik ekstrak, uji spesifik ekstrak dan uji kandungan kimia ekstrak.

Susut pengeringan yaitu pengukuran sisa zat setelah pengeringan pada temperatur $105^{\circ} \mathrm{C}$ selama 30 menit atau sampai berat konstan. Tujuan dari penentuan susut pengeringan adalah memberikan batasan maksimal (rentang) tentang besarnya senyawa yang hilang pada proses pengeringan (Departemen Kesehatan Republik Indonesia, 2000). Pada penentuan susut pengeringan ekstrak daun kirinyuh didapatkan persentase rata-rata adalah 9,76\%.

Kadar abu yaitu bahan dipanaskan pada temperatur di mana senyawa organik dan turunannya terdestruksi dan menguap sehingga yang tertinggal hanya unsur mineral dan anorganik. Tujuan dilakukan penentuan kadar abu adalah untuk memberikan gambaran kandungan mine-

Tabel 1 Karakteristik Ekstrak

\begin{tabular}{|l|l|}
\hline \multicolumn{1}{|c|}{ Pemeriksaan } & \multicolumn{1}{c|}{ Pengamatan } \\
\hline Warna & Hijau pekat \\
\hline Bau & Khas aromatis \\
\hline Rasa & Pahit \\
\hline Bentuk & Kental \\
\hline Alkaloid & + \\
\hline Flavonoid & + \\
\hline Steroid & + \\
\hline Terpenoid & - \\
\hline Saponin & + \\
\hline Susut pengeringan & $9,76 \%$ \\
\hline Kadar abu & $4,8513 \%$ \\
\hline Kadar senyawa larut air & $9,8067 \%$ \\
\hline
\end{tabular}


ral internal dan eksternal yang berasal dari proses awal sampai terbentuknya ekstrak (Departemen Kesehatan Republik Indonesia, 2000). Pada penentuan kadar abu ekstrak daun kirinyuh didapat persen rata-rata adalah 4,8513\% (Tabel 1).

Hewan percobaan yang digunakan dalam penelitian ini yaitu mencit putih jantan, adapun alasan pemakaian mencit sebagai hewan percobaan didasarkan pada kemiripan fisiologis dengan manusia dan mencit mudah ditangani, relatif murah, mudah didapat, kecil, kandang tidak terlalu besar, omnivora, sistem operasi mudah (Thompson, 1985).

Hewan percobaan diaklimatisasi selama 7 hari sebelum perlakuan, tujuannya untuk penyesuaian terhadap kondisi lingkungan. Setelah itu mencit diberi suspensi ekstrak satu kali pemberian dalam waktu 24 jam dengan dosis yang digunakan adalah 4g/kg BB, $8 \mathrm{~g} / \mathrm{kg} \mathrm{BB}$, dan 16 $\mathrm{g} / \mathrm{kg} \mathrm{BB}$, kemudian mencit yang masih hidup dilakukan pengamatan toksisitas tertunda pada hari ke 3, 5, 7, 10, 12, dan 14. Parameterparameter yang diamati pada kelompok perlakuan dibandingkan dengan kelompok pembanding yaitu kelompok kontrol.

Sediaan uji dibuat dalam bentuk suspensi karena ekstrak tidak mudah larut dalam air agar bias terdispersi sempurna. Suspending agen yang digunakan Na CMC 0,5\%. Dengan konsentrasi ini ekstrak sudah dapat larut baik dan konsentrasi ini umum dipakai untuk sediaan dengan jalur oral (Sumarni et al., 2006).

Pada penelitian ini dilakukan uji toksisitas akut di mana sampai dosis $16 \mathrm{~g} / \mathrm{KgBB}$ tidak ada hewan yang mati, untuk itu penentuan LD50 tidak dilanjutkan lagi karena hasil ini menunjukkan bahwa ekstrak etanol daun kirinyuh (Chromolaena odorata (L) R.M. King \& H. Rob) termasuk kategori praktis tidak toksik karena mempunyai LD50 > $15 \mathrm{~g} / \mathrm{KgBB}$, dapat dilihat pada Tabel 2. Hasil penelitian menunjukkan bahwa pada hari ke-14 terlihat pertambahan berat badan baik hewan kelompok kontrol maupun hewan perlakuan (seluruh variasi dosis). Berat badan ditentukan oleh keseimbangan antara masukan kalori dan pelepasan energi. Dengan cara tertentu berat badan dipertahankan pada titik tertentu. Nafsu makan diatur oleh hipotalamus melalui interaksi antara "pusat makanan” dan "pusat kenyang” (Guyton, 1995).

Tabel 2 Tingkatan Toksisitas Berdasarkan Harga LD50

\begin{tabular}{|l|l|}
\hline \multicolumn{1}{|c|}{ Tipe } & \multicolumn{1}{c|}{ Letal Dosis (LD50) } \\
\hline Praktis tidak toksik & $>15 \mathrm{~g} / \mathrm{kgBB}$ \\
\hline Sedikit toksik & $5-15 \mathrm{~g} / \mathrm{kgBB}$ \\
\hline Agak toksik & $0,5-5 \mathrm{~g} / \mathrm{kgBB}$ \\
\hline Toksik & $50-500 \mathrm{mg} / \mathrm{kgBB}$ \\
\hline Sangat toksik & $5-50 \mathrm{mg} / \mathrm{kgBB}$ \\
\hline Super toksik & $<5 \mathrm{mg} / \mathrm{kgBB}$ \\
\hline
\end{tabular}

Pada evaluasi toksisitas akut ini diamati dan diperiksa beberapa parameter lain: berat badan, volume air minum, dan berat relatif organ.

Didapatkan data yang cukup beragam pada masing-masing kelompok hewan percobaan. Perbedaan yang timbul merupakan suatu kewajaran karena perbedaan kondisi fisiologis seperti berat badan, usia, dan proses metabolisme tubuh dari masing-masing hewan percobaan selama perlakuan. Hal tersebut akan memengaruhi parameter-parameter yang diukur (Wood, 1999).

Berdasarkan perhitungan statistik dari data pengujian berat badan diketahui bahwa nilai signifikan perlakuan dosis yaitu $0,000(\mathrm{P}<0,05)$ maka dapat disimpulkan bahwa variasi dosis ekstrak daun kirinyuh berpengaruh nyata pada berat badan dari mencit putih jantan. Pada peng- 
ujian terhadap waktu, diketahui nilai signifikansi 0,364 $(\mathrm{P}<0,05)$ maka dapat disimpulkan bahwa tidak ada pengaruh waktu terhadap berat badan mencit putih jantan pada hari ke-3, 5, 7, 10, 12 dan 14 dari ekstrak daun kirinyuh. Sedangkan pada pengujian terhadap interaksi perlakuan dan waktu adalah $0,999(\mathrm{P}<0,05)$ maka dapat disimpulkan bahwa tidak ada interaksi antara variasi dosis ekstrak daun kirinyuh dengan waktu terhadap berat badan mencit putih jantan. Berdasarkan hasil uji lanjut duncan ternyata menunjukkan bahwa terdapat perbedaan berat badan mencit antara dosis $4 \mathrm{~g} / \mathrm{KgBB}, 8 \mathrm{~g} / \mathrm{KgBB}$ dan 16 $\mathrm{g} / \mathrm{KgBB}$ dengan kontrol (Gambar 1).

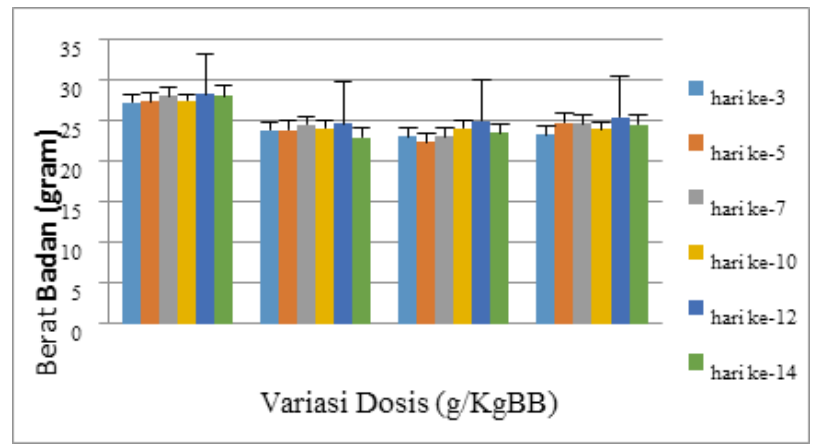

Gambar 1 Pengaruh Dosis Ekstrak Daun Kirinyuh (Chromolaena Odorata (L) R.M. King \& H. Rob)

Terhadap Berat Badan Mencit Putih Jantan

Pada pengamatan untuk volume air minum tiap-tiap hari didapatkan bahwa puncak tertinggi dan terendah volume air minum hewan percobaan baik kelompok kontrol maupun kelompok perlakuan berbeda-beda waktunya. Berdasarkan perhitungan statistik dari data pengujian volume air minum diketahui bahwa pengujian terhadap perlakuan dosis signifikansinya yaitu 0,000 $(\mathrm{P}<0,05)$ maka dapat disimpulkan bahwa variasi dosis ekstrak daun kirinyuh berpengaruh nyata terhadap volume air minum dari mencit putih jantan. Pada pengujian terhadap waktu, diketahui signifikansi 0,000 $(\mathrm{P}<0,05)$ maka dapat disimpulkan bahwa ada pengaruh waktu terhadap volu- me air minum mencit putih jantan. Sedangkan pengujian terhadap interaksi dosis dan waktu adalah 0,000 $(\mathrm{P}<0,05)$ maka dapat disimpulkan ada interaksi antara variabel dosis dengan waktu terhadap volume air minum mencit putih jantan.

Berdasarkan hasil uji lanjut duncan ternyata menunjukkan bahwa ada perbedaan terhadap volume air minum mencit antara dosis $4 \mathrm{~g} / \mathrm{KgBB}, 8$ $\mathrm{g} / \mathrm{KgBB}$ dan $16 \mathrm{~g} / \mathrm{KgBB}$ dengan kontrol maka dianggap perbedaan volume air minum merupakan suatu tanda telah terjadi gangguan pada aktivitas minum hewan percobaan (Gambar 2).

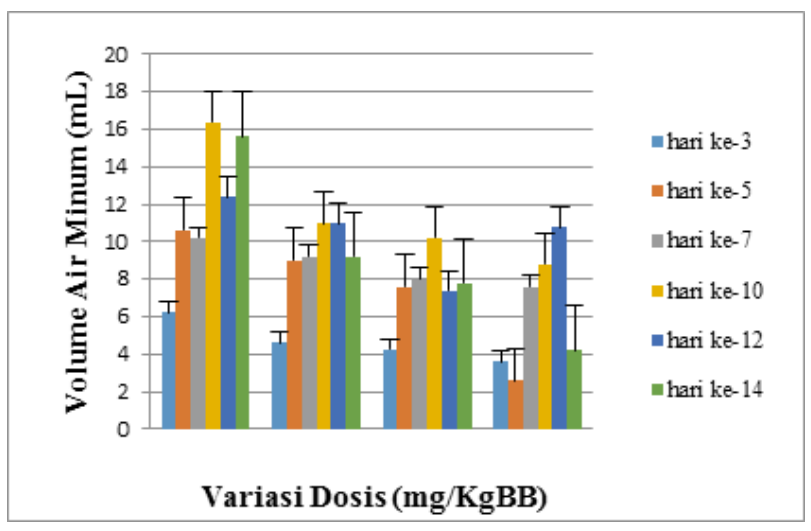

Gambar 2 Pengaruh Dosis Ekstrak Daun Kirinyuh (Chromolaena Odorata (L) R.M. King \& H. Rob) Terhadap Volume Air Minum Mencit Putih Jantan

Parameter lain yang diamati adalah rasio berat relatif organ. Organ yang diamati adalah paru-paru, jantung, lambung, hati dan ginjal. Rasio berat organ biasanya merupakan petunjuk sangat peka dari efek toksik. Organ-organ ini dapat dirusak berbagai jenis zat kimia yang bekerja secara langsung pada organ sasaran ataupun secara tidak langsung yakni melalui susunan saraf pusat atau pembuluh darah. Jantung mudah mengalami kelainan yang diakibatkan senyawa-senyawa kimia, karena mitokondria yang terdapat di otot jantung dengan jumlah yang relatif besar lebih sering menjadi sasaran kardiotoksisitas (Lu, 1995). 
Dari pengujian statistik anova satu arah berat relatif organ jantung didapatkan signifikansi 0,053 $(\mathrm{P}<0,05)$ maka dapat disimpulkan tidak ada pengaruh variasi dosis terhadap berat relatif organ jantung dari mencit putih jantan.

Karena kita menggunakan rute oral maka senyawa uji akan mengalami siklus enterohepatik, setelah terjadi absorbsi pada saluran cerna, maka senyawa akan dibawa oleh vena porta menuju hati. Sekitar $80 \%$ darah yang ada dalam hati berasal dari vena porta, sehingga hati sering menjadi organ sasaran senyawa toksik di dalam tubuh (Lu, 1995). Hati merupakan organ yang memiliki kemampuan untuk pemulihan kerusakan sel yang sangat besar. Hati memiliki enzim sitokrom p-450 yang dapat memetabolisme zat asing di dalam tubuh, dengan membuat sebagian toksikan menjadi kurang toksik dan lebih mudah larut dalam air (Sherlock, 1990).

Berat relatif organ biasanya merupakan petunjuk yang sangat peka dari efek pada hati. Dari hasil pengujian statistik anova satu arah didapatkan nilai signifikan yaitu $0,410(\mathrm{P}<0,05)$ maka dapat disimpulkan tidak ada pengaruh variasi dosis terhadap berat relatif organ hati dari mencit putih jantan.

Berat relatif organ ginjal kelompok kontrol tidak berbeda jauh dibandingkan dengan kelompok perlakuan yang diberi ekstrak etanol daun kirinyuh, dari hasil pengujian statistik anova satu arah didapatkan nilai signifikan yaitu 0,346 $(\mathrm{P}<0,05)$ maka dapat disimpulkan tidak ada pengaruh variasi dosis terhadap berat relatif organ ginjal dari mencit putih jantan.

Berat relatif organ lambung kelompok kontrol cukup berbeda dibandingkan dengan kelompok perlakuan yang diberi ekstrak daun kirinyuh, dari hasil pengujian statistik anova satu arah didapatkan nilai signifikan yaitu 0,020 $(\mathrm{P}<0,05)$ maka dapat disimpulkan ada pengaruh variasi dosis ekstrak daun kirinyuh terhadap berat relatif organ lambung dari mencit putih jantan. Setelah dilakukan uji lanjut duncan menunjukkan perbedaan terhadap berat relatif organ lambung antara dosis $16 \mathrm{~g} / \mathrm{KgBB}$ dan kelompok kontrol dengan dosis $8 \mathrm{~g} / \mathrm{KgBB}$.

Berat relatif organ paru-paru kelompok kontrol berbeda dibandingkan dengan kelompok perlakuan yang diberi ekstrak daun kirinyuh, dari hasil pengujian statistik anova satu arah didapatkan nilai signifikan yaitu 0,000 karena $(\mathrm{P}<0,05)$ maka dapat disimpulkan ada pengaruh variasi dosis ekstrak daun kirinyuh terhadap berat relatif organ paru-paru dari mencit putih jantan. Setelah dilakukan uji lanjut duncan menunjukkan perbedaan terhadap berat relatif organ paru-paru antara dosis $4 \mathrm{~g} / \mathrm{KgBB}, 8 \mathrm{~g} /$ $\mathrm{KgBB}$ dan kelompok kontrol dengan dosis $16 \mathrm{~g} /$ KgBB (berdasarkan Gambar 3).

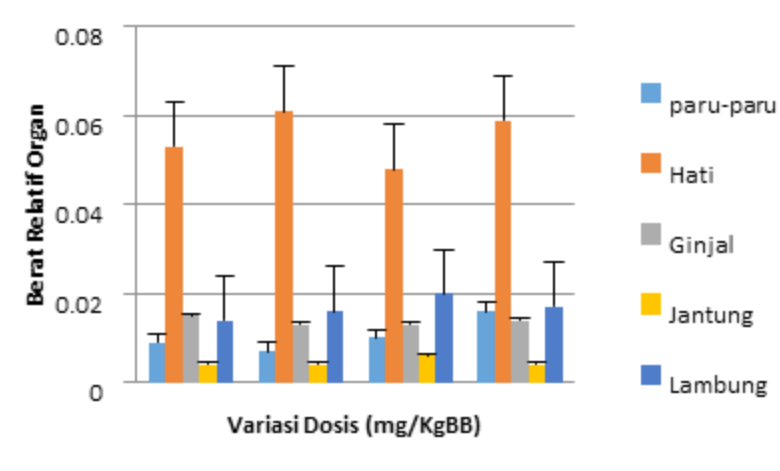

Gambar 3 Pengaruh Dosis Ekstrak Daun Kirinyuh (Chromolaena Odorata (L) R.M.King \& H. Rob) Terhadap Berat Relatif Organ pada Mencit Putih Jantan

\section{KESIMPULAN}

Dari hasil penelitian yang telah dilakukan dapat diambil kesimpulan sebagai berikut.

1. Ekstrak daun kirinyuh (Chromolaena odorata (L) R.M. King \& H. Rob) termasuk kategori 
praktis tidak toksik karena mempunyai LD50 $>15 \mathrm{~g} / \mathrm{KgBB}$.

2. Toksisitas terunda terlihat dari ekstrak daun kirinyuh (Chromolaena odorata (L) R.M. King \& H. Rob) dengan dosis $4 \mathrm{~g} / \mathrm{KgBB}, 8 \mathrm{~g} / \mathrm{KgBB}$ dan $16 \mathrm{~g} / \mathrm{KgBB}$ menimbulkan efek toksik pada berat badan, volume air minum, berat relatif organ lambung dan paru-paru secara bermakna $(\mathrm{P}<0,05)$. Sedangkan pada berat relatif organ jantung, ginjal dan organ hati tidak menimbulkan efek toksik secara bermakna $(\mathrm{P}<0,05)$.

\section{DAFTAR PUSTAKA}

Badan Pengawas Obat dan Makanan Republik Indonesia. 2014. Peraturan Kepala Badan Pengawas Obat dan Makanan Republik Indonesia Nomor 12 Tahun 2014 tentang Persyaratan Mutu Obat Tradisional. Jakarta: Badan Pengawas Obat dan Makanan.

Dalimartha, S. 2000. Atlas Tumbuhan Indonesia. (Jilid II). Jakarta: Trubus Agriwidya.

Departemen Kesehatan Republik Indonesia. 1980. Materia Medika Indonesia (Jilid IV). Jakarta: Departemen Kesehatan Republik Indonesia.

Departemen Kesehatan Republik Indonesia. 1985. Cara Pembuatan Simplisia. Jakarta: Departemen Kesehatan Republik Indonesia.

Departemen Kesehatan Republik Indonesia. 2000. Parameter standar umum Ekstrak Tumbuhan Obat. (Edisi I). Jakarta: Departemen Kesehatan Republik Indonesia.

Departemen Kesehatan Republik Indonesia. 2008. Farmakope Herbal Indonesia (Edisi I). Jakarta: Departemen Kesehatan Republik Indonesia.
Guyton, A.C. 1995. Fisiologi Kedokteran. (Edisi 17). Penerjemah: Arrianti, L.M. Jakarta: Penerbit Buku Kedokteran Indonesia EGC. Inya-agha, S.I., Oguntimein, B.O., Sofowora. A., \& Benjamin, V.T. (1987). Phytochemical and Antibacterial Studies on the Essential Oil of Eupatorium Odoratum. International Journal Crude Drug Research, 25, (1), 49-52.

Jones, D.S. 2010. Statistika Farmasi. Penerjemah: H.U. Ramadaniati H. Rivai. Jakarta: Penerbit Buku Kedokteran EGC.

Koeman, J.H. 1987. Pengantar Umum Toksikologi. Penerjemah: R. H. Yudono. Yogyakarta: Gadjah Mada University Press.

Lu, F.C. 1995. Toksikologi Dasar: Asas, Organ Sasaran, dan Penilaian Risiko, (edisi 2). Penerjemah: E. Nugraha. Jakarta: UI press. Price, S.A. \& Wilson, L.M. 2005. Patofisiologi Konsep Klinis Proses-Proses Penyakit, (Edisi VI). Volume I. Jakarta: Penerbit Buku Kedokteran EGC.

Sherlock, S. 1990. Penyakit Hati dan Sistem Saluran Empedu. Penerjemah: P. Andrianto. Jakarta: Widya Madika.

Sumarni, R.D., Parodi, \& Darmono. 2006. Pengaruh Pemberian Ekstrak Kering Rimpang Temu Putih (Curcuma Zedoria, Rosc) per Oral terhadap Beberapa Parameter Gangguan Ginjal pada Tikus Putih Jantan. Jurnal Farmasi Indonesia, Vol. 17 (1).

Thompson, E. (1985). Drug and Bioscreening Fundamentals of Drugs Evaluation Technique in Pharmacology. New York: Graceway Publishing Company.

Vital, P.G., \& Rivera, W.L. 2009. Antimicrobacterial Activity and Citoxcity of Chromolaena Odorata (L.f) King and Robinson and Uncaria Perrottetti (A. Rich) Merr. 
Extracts. Journal of medicinal palnt research, 03, (7), 511-518.

Wood, J. 1999. Gout and Management. The Pharmaceutical Journal, 262, (5), 808811.
Yenti, R., Afrianti, R., \& Afriani, L. 2011. Formulasi krim ekstrak etanol daun kirinyuh (Euphatorium odorata.L) untuk penyembuhan luka. Majalah Kesehatan Pharma Medika, 3. (1), 227-230. 